Original Paper http://ajol.info/index.php/ijbcs http://indexmedicus.afro.who.int

\title{
Haematological and biochemical studies on the effect of diclofenac sodium on Wistar Rattus norvegicus
}

\author{
Orinya Agbaji ORINYA, Adeshina Yahaya ADENKOLA and Raphael John OGBE* \\ Department of Veterinary Physiology, Pharmacology and Biochemistry, College of Veterinary Medicine, \\ Federal University of Agriculture, P.M.B. 2373, Makurdi, Benue State, Nigeria. \\ *Corresponding author; E-mail: ralphjohn2012@gmail.com,ogbe.raphael@uam.edu.ng, \\ Tel.: +2348065300976.
}

\begin{abstract}
Diclofenac sodium is a non-steroidal anti-inflammatory drug commonly used worldwide for the treatment of inflammation and pain due to arthritis or other ailments in man and animals. Despite these benefits, there are concerns that this drug may have adverse effect on animal's liver and kidneys. This work was designed to determine the effect of diclofenac sodium on blood components using haematological tests, as well as determine the hepatotoxic and nephrotoxic effects using biochemical assays. Twenty rats were randomly divided into four groups with 5 rats per group. The groups 2, 3, and 4 were assigned rats, intramuscularly administered diclofenac sodium at the doses of $49.05,98.10$ and $147.15 \mathrm{mg} / \mathrm{kg}$ body weight respectively, once a day for seven days while group 1 rats were given distilled water only, and served as control. The blood collected was tested by haemoanalyzer while the serum was assayed by biochemistry analyzer. The various doses of diclofenac sodium produced significant $(p<0.05)$ decrease in the values of haemoglobin concentration, packed cell volume, red blood cells and white blood cells while there was significant $(\mathrm{p}<0.05)$ increase in the levels of serum alanine aminotransferase, aspartate aminotransferase, alkaline phosphatase, total bilirubin, urea, creatinine, total cholesterol, triglycerides and electrolytes. However, there was significant $(\mathrm{p}<0.05)$ decrease in the levels of serum total protein, albumin, glucose and HDLcholesterol. The results therefore showed that diclofenac sodium may have deleterious effect on animal tissues, resulting in hepatic and renal impairments at the given doses and treatment duration. So caution needs to be exercised in its administration, which should be limited to the lowest therapeutic doses, to prevent its harmful effect.
\end{abstract}

(C) 2016 International Formulae Group. All rights reserved.

Keywords: Nephrotoxicity, hepatotoxicity, haematotoxicity, Non-steroidal anti-inflammatory drugs

\section{INTRODUCTION}

The liver, gastrointestinal tract, lungs and kidneys, are organs of drug metabolism, with the liver being the chief organ of drug biotransformation (Neal, 2012). Drug metabolism also known as xenobiotic metabolism is the biochemical modification of pharmaceutical substances or foreign compounds by living organisms, usually through specialized enzymatic systems. Xenobiotics metabolism involves set of metabolic pathways that modify the chemical 
structures of xenobiotics, which are compounds foreign to the normal biochemistry of organisms. The reactions often act to detoxify poisonous compounds; however, in some cases the intermediates formed during xenobiotic metabolism themselves can have toxic effects on living tissues (Wikipedia, 2009; da Silva et al., 2013). Thus, the liver, kidneys and blood cells are greatly affected by drug-induced toxicity.

Non-steroidal anti-inflammatory drugs (NSAIDs) are widely employed in the treatment of musculoskeletal diseases, both for their anti-inflammatory activities as well as their analgesic properties (Crofford, 2013). They exert their anti-inflammatory, antipyretic and analgesic effects via the suppression of prostaglandins (PGs) synthesis, by inhibiting the enzyme, cyclooxygenase (COX), which has two isoforms, COX-1 and COX-2 (Hörl, 2010). They inhibit both COX-1 and COX-2, the rate-limiting enzymes for the production of prostaglandins and thromboxane (Harris, 2006). COX-1 functions mainly in the control of renal haemodynamics and glomerular filtration rate (GFR), while COX-2 functions primarily affect salt and water excretion (Weir, 2002). The use of these agents therefore may lead to adverse effects on body tissues or cause cellular injuries, ranging from acute to long-term chronic disorders and may include conditions considered to be degenerative. These include alterations in renal function, effects on blood pressure, hepatic injury, platelet inhibition, gastrointestinal and cardiovascular disorders (Lo et al., 2006; Ong et al., 2007). However, the use of lowest effective dose of a given NSAID will reduce the incidence of the drug adverse effects and complications (Ong et al., 2007).

Among the NSAIDs, diclofenac sodium is a widely circulated drug, used both in humans and animals for the treatment and management of inflammation, fever and pain associated with disease or injury of domestic livestock and humans. Diclofenac sodium is a phenylacetic acid derivative; a non-steroidal anti-inflammatory drug (NSAID), which has been used by humans for many years. It is indicated for the treatment of pain due to osteoarthritis/rheumatoid arthritis, various inflammatory and degenerative post-traumatic disorders, as well as pre-operative treatment including cataract extraction (Boothe, 2001). As a result of the drug's inhibitory effect on cyclooxygenase, it inhibits prostaglandins biosynthesis from arachidonic acid (Ahmad et al., 2012). Prostaglandins play a role in maintaining GFR, and this is especially critical for the maintenance of GFR in volume depleted states (Dhanvijay et al., 2013). The drug is efficiently absorbed from the gastrointestinal tract and has a short elimination half-life of $2-3$ hours in most species including humans, with an average of 1.5 hours in plasma but accumulates at the site of inflammation and tends to persist in synovial fluid (El-Maddawy and ElAshmawy, 2013).

Despite its beneficial effects, several studies conducted around the world indicate that diclofenac sodium may be associated with adverse effects on the liver and kidneys (Aydin et al., 2003; Ahmad et al., 2012; ElMaddawy and El-Ashmawy, 2013). Thus, there are increasing concerns among medical practitioners that treatment of inflammation with diclofenac sodium might cause hepatocellular and renal injuries in humans, at certain doses and treatment regimens. In addition, there is an increase in the use of diclofenac sodium for the treatment of pain and inflammatory disorders in veterinary clinical practice, but there appears to be paucity of information on the standard dosage and effect of the drug on haematological and biochemical parameters of animals. Thus, this study was designed to investigate the effect of diclofenac sodium on haematological and biochemical parameters of albino Wistar rats, with a view to evaluate its toxic effect on their blood cells, liver and kidney tissues, and possibly to ascertain the safe dose of the drug. 


\section{MATERIALS AND METHODS}

Diclofenac sodium manufactured by Laborate Pharmaceuticals Ltd, India and marketed in Nigeria by EMBASSY Pharmaceuticals and Chemical Ltd, Lagos, Nigeria, with Batch Number EDKFI-001 and NAFDAC Registration number A4-0035 Hp/DRUGS/MIS/04/87 was used. Each milliliter contains diclofenac sodium, $25 \mathrm{mg}$, Benzyl Alcohol, 4\% v/v (as preservative). The other materials are distilled water, normal laboratory glass wares, instruments and reagents of analytical grade.

\section{Experimental animals and management}

A total of thirty (30) female rats which weighed between 125.00 to $200.00 \mathrm{~g}$ were obtained from the animal house of the College of Medical Sciences, Benue State University, Makurdi, Benue State. All the rats were fed with commercial animal feeds produced by Grand Cereals and Oil Mills Limited (GCOML), Jos and clean water was provided ad libitum. The animals were handled according to the International guidelines and principles for biomedical research involving animals (Suckow et al., 2012) and certified by the Animal Ethics Committee of the Department of Veterinary Physiology, Pharmacology and Biochemistry, University of Agriculture, Makurdi, Benue state, Nigeria.

\section{Acute toxicity test of diclofenac sodium}

The Up and Down procedure was used to estimate the median lethal dose $\left(\mathrm{LD}_{50}\right)$ of the drug (Akhila et al., 2007; Saganuwan, 2012). A total of six (6) female rats weighing $172.50 \pm 12.16 \mathrm{~g}$ were used for estimation of the $\mathrm{LD}_{50}$. The dosing pattern is characterized by survival or death of the experimental animals. Selection of the starting dose was based on available information and results of previous toxicity studies on the test material. The first animal was dosed a step below the toxicologist's best estimate of the $\mathrm{LD}_{50}$. A starting dose of $110 \mathrm{mg} / \mathrm{kg}$ was selected for the first animal. The $2^{\text {nd }}, 3^{\text {rd }}, 4^{\text {th }}, 5^{\text {th }}, 6^{\text {th }}$, animals received $350 \mathrm{mg} / \mathrm{kg}, 110 \mathrm{mg} / \mathrm{kg}, 350$ $\mathrm{mg} / \mathrm{kg}, 110 \mathrm{mg} / \mathrm{kg}$ and $350 \mathrm{mg} / \mathrm{kg}$ respectively via intramuscular route of administration. Acute toxicity signs, death and survival status of each animal was recorded.

\section{Experimental design and grouping of animals}

Twenty (20) female rats were randomly selected and divided into four (4) groups 1, 2, 3 and 4, with five animals per group. Each of the rats in treatment group 2, 3 and 4 was administered $49.05 \mathrm{mg} / \mathrm{kg}, 98.10 \mathrm{mg} / \mathrm{kg}$, and $147.15 \mathrm{mg} / \mathrm{kg}$ body weight respectively, corresponding to $25 \%, 50 \%$, and $75 \%$ of the $\mathrm{LD}_{50}$ value of diclofenac sodium, using intramuscular $(\mathrm{i} / \mathrm{m})$ route for a period of 7 days while the group 1 rats (control) received distilled water only. Meanwhile, the rats were weighed on each of the days before administration of the drug. After the last day of drug administration, $2 \mathrm{ml}$ of blood was obtained from each rat by cardiac puncture, with needle and syringe under the effect of anaesthesia using chloroform. Then $1 \mathrm{ml}$ of blood was placed in a tube containing EDTA (Ethylene Diamine Tetraacetic acid) as anticoagulant while the remaining blood was dispensed into another tube and allowed to clot. The anti-coagulated blood was used for the estimation of haematological parameters while the clotted blood was centrifuged at $1500 \mathrm{x} \mathrm{g}$ for 15 minutes and the resultant serum harvested, stored frozen until it is used for biochemical analysis.

\section{Determination of haematological parameters}

The haematological parameters were estimated with the anticoagulated blood. Automated haemoanalyzer with the appropriate reagents were used to determine all the clinical haematological parameters; following the procedures in the operations manual, according to the principles earlier described (Cheesbrough, 2002). The haematological parameters determined include Erythrocytes or Red blood cells (RBC) count, Packed cell volume (PCV), Haemoglobin 
(Hb) concentration, total Leukocytes or White blood cells (WBC) count, Monocytes count, Platelets count, Lymphocytes count and Granulocytes count while the values of Mean corpuscular volume (MCV), Mean corpuscular haemoglobin concentration (MCHC), Mean corpuscular haemoglobin $(\mathrm{MCH})$ were calculated from the values of total $\mathrm{RBC}, \mathrm{PCV}$ and $\mathrm{Hb}$ determined (Baker et al., 2001).

\section{Biochemical assays}

The sera were harvested with clean Pasteur pipettes while assays for biochemical parameters were performed using an automated Biochemistry analyzer (Hitachi 902, Germany), according to the principles of biochemical analysis (Vasudevan and Sreekumari, 2007). The clinical biochemical parameters assayed include Aspartate aminotransferase (AST or SGOT), Alanine aminotransferase (ALT or SGPT), Alkaline phosphatase (ALP), Glucose, Creatinine, Urea, Albumin, Total protein, Total bilirubin, Triglycerides, Total cholesterol, High density lipoprotein (HDL) cholesterol, Low density lipoprotein (LDL) cholesterol, and the electrolytes such as Sodium $\left(\mathrm{Na}^{+}\right)$, Potassium $\left(\mathrm{K}^{+}\right)$and Chloride $\left(\mathrm{Cl}^{-}\right)$ions using standard assay kits and according to the procedures in the manual (Roche diagnostics Ltd, United Kingdom).

\section{Statistical analysis}

Statistical package for social sciences (SPSS) was used for the statistical analysis. Results were expressed as mean \pm standard error of mean (SEM), $(n=5)$ and statistically analyzed by one-way analysis of variance (ANOVA), followed by Duncan multiple range test, to determine significant difference between group means. The difference between groups were considered significant at $\mathrm{p}<0.05$.

\section{RESULTS}

The median lethal dose $\left(\mathrm{LD}_{50}\right)$ of diclofenac sodium was estimated to be
$196.2 \mathrm{mg} / \mathrm{kg}$ body weight by intramuscular (i.m.) route of administration. The toxicity signs observed are rapid respiration, recumbency, paralysis, gasping for air, gastrointestinal bleeding, coma and death after administration of higher doses of the drug.

\section{Haematological findings}

The value of PCV $(36.5 \pm 0.00 \%)$ for group 2 was significantly $(\mathrm{p}<0.05)$ higher than the value of the control $(26.1 \pm 5.34 \%)$ while the values for group $3(17.2 \pm 5.03 \%)$ and $4 \quad(15.6 \pm 0.00 \%)$ were significantly $(p<0.05)$ lower than the control. The same trend was seen in the values of haemoglobin concentrations, in which the lowest value of $4.60 \pm 0.00 \mathrm{~g} / \mathrm{dl}$ was obtained in group 4 . There was a significant $(\mathrm{p}<0.05)$ decrease in the value of $\mathrm{RBC}$ of group $3\{2.97 \pm 0.91$ $\left.\left(\times 10^{6} / \mu \mathrm{L}\right)\right\}$, when compared with the value of the control $\left\{4.46 \pm 0.89\left(\times 10^{6} / \mu \mathrm{L}\right)\right\}$. There were also significantly $(\mathrm{p}<0.05)$ lower values of total WBC in group $2\{2.80 \pm 0.00$ $\left.\left(\mathrm{x} 10^{3} / \mu \mathrm{L}\right)\right\}$, group $3\left\{4.90 \pm 1.34\left(\times 10^{3} / \mu \mathrm{L}\right)\right\}$, and group $4\left\{4.90 \pm 0.00\left(\times 10^{3} / \mu \mathrm{L}\right)\right\}$, when compared with the control $\{6.65 \pm 1.65$ $\left.\left(\mathrm{x} 10^{3} / \mu \mathrm{L}\right)\right\}$. Lymphocytes and Granulocytes counts in the treated groups also showed significant $(p<0.05)$ decreases when compared with the control. The value of mean corpuscular haemoglobin concentration (MCHC) was significantly $(\mathrm{p}<0.05)$ lower in group 4 when compared with the control. The values of MCV and $\mathrm{MCH}$ in the group 2 and group 4 respectively were significantly $(p<0.05)$ higher than the control. However, a significantly $(p<0.05)$ lower value was obtained for platelet counts in group 3, while there was significant $(\mathrm{p}<0.05)$ elevation in platelet counts of group 2 and 4 in comparison with the control (Table 1).

\section{Biochemical Findings}

There was significant $(\mathrm{p}<0.05)$ reduction of the glucose levels in groups 2 and 3 when compared with the control, with 
value of $57.65 \pm 18.38 \mathrm{mg} / \mathrm{dl}$. There was significant $(p<0.05)$ elevation in the levels of transaminases (ALT and AST) of groups $2 \& 4$ over the controls, with values of $93.75 \pm 9.62 \mathrm{IU} / \mathrm{L}$ and $276.13 \pm 51.87 \mathrm{IU} / \mathrm{L}$ respectively. The ALP levels in groups 2 and 3 were significantly $(p<0.05)$ higher than the control, which has a level of $153.00 \pm 3.89 \mathrm{IU} / \mathrm{L}$. The levels of total proteins of group 3 and 4 were significantly $(\mathrm{p}<0.05)$ lower than the control with value of $6.85 \pm 0.18 \mathrm{~g} / \mathrm{dl}$, while a similar trend was observed with albumin levels, as the levels of serum albumin showed significant $(\mathrm{p}<0.05)$ reduction in all treatment groups when compared with the control $(3.95 \pm 0.25$ $\mathrm{g} / \mathrm{dl})$. There was significant $(\mathrm{p}<0.05)$ elevation in the levels of total bilirubin in all the treatment groups when compared with the control with the value of $1.13 \pm 0.75$ $\mu \mathrm{mol} / \mathrm{L}$.

Serum urea levels showed significant $(p<0.05)$ elevation in all treatment groups in comparison with the control $(8.20 \pm 0.68$ $\mathrm{mg} / \mathrm{dl})$. The serum creatinine levels also showed similar patterns to that of urea, with significant $(p<0.05)$ increase in the creatinine levels of all the treatment groups when compared with the control $(48.34 \pm 3.35 \mu \mathrm{mol} / \mathrm{L})$. The levels of serum sodium, potassium and chloride ions (electrolytes) in group 4 were significantly $(p<0.05)$ higher than the controls. There was a significant $(p<0.05)$ elevation of total cholesterol levels in group 2 over the control $(59.50 \pm 4.21 \mathrm{mg} / \mathrm{dl})$ and a significant $(p<0.05)$ decrease in the levels of HDL cholesterol in all treatment groups when compared with the control $(1.21 \pm 0.06$ $\mathrm{mmol} / \mathrm{L})$. There was also significantly $(\mathrm{p}<0.05)$ higher levels of triglycerides in all the treatment groups in comparison with the control, with a value of $66.00 \pm 15.16 \mathrm{mg} / \mathrm{dl}$ (Table 2).

Table 1: Effect of diclofenac sodium on haematological indices of albino Wistar rats.

\begin{tabular}{|c|c|c|c|c|}
\hline \multirow[b]{2}{*}{ Parameters } & \multicolumn{4}{|c|}{ Doses of diclofenac sodium (mg/kg body weight) } \\
\hline & $\begin{array}{l}\text { Group } 1 \\
\text { (control) }\end{array}$ & Group 2 (49.05) & $\begin{array}{l}\text { Group } 3 \\
(98.10)\end{array}$ & $\begin{array}{l}\text { Group } 4 \\
(147.15)\end{array}$ \\
\hline Packed cell volume (\%) & $26.08 \pm 5.34^{\mathrm{a}}$ & $36.5 \pm 0.00^{\mathrm{b}}$ & $17.2 \pm 5.03^{b}$ & $15.60 \pm 0.00^{\mathrm{b}}$ \\
\hline Haemoglobin conc. (g/dL) & $7.80 \pm 1.49^{\mathrm{a}}$ & $10.80 \pm 0.00^{\mathrm{a}}$ & $5.50 \pm 1.68^{\mathrm{b}}$ & $4.60 \pm 0.00^{\mathrm{b}}$ \\
\hline Red blood cells $\left(\times 10^{6} / \mu \mathrm{L}\right)$ & $4.46 \pm 0.89^{\mathrm{a}}$ & $5.98 \pm 0.00^{\mathrm{a}}$ & $2.97 \pm 0.91^{\mathrm{b}}$ & - \\
\hline $\begin{array}{l}\text { White blood cells counts } \\
\left(\times 10^{3} / \mu \mathrm{L}\right)\end{array}$ & $6.65 \pm 1.65^{\mathrm{a}}$ & $2.80 \pm 0.00^{\mathrm{b}}$ & $4.90 \pm 1.34^{\mathrm{b}}$ & $4.90 \pm 0.00^{\mathrm{b}}$ \\
\hline Granulocytes counts $\left(\times 10^{3} / \mu \mathrm{L}\right)$ & $2.55 \pm 1.25^{\mathrm{a}}$ & $0.70 \pm 0.00^{\mathrm{b}}$ & $2.40 \pm 0.00^{\mathrm{a}}$ & $1.10 \pm 0.00^{\mathrm{b}}$ \\
\hline Lymphocytes counts $\left(\times 10^{3} / \mu \mathrm{L}\right)$ & $3.93 \pm 0.93^{\mathrm{a}}$ & $2.20 \pm 0.00^{\mathrm{b}}$ & $2.20 \pm 0.00^{\mathrm{b}}$ & $2.90 \pm 0.00^{\mathrm{a}}$ \\
\hline Monocytes counts $(x 103 / \mu \mathrm{L})$ & $0.93 \pm 0.35^{\mathrm{a}}$ & $0.20 \pm 0.00^{\mathrm{a}}$ & $2.80 \pm 0.00^{\mathrm{b}}$ & $0.90 \pm 0.00^{\mathrm{a}}$ \\
\hline Platelets counts $\left(\times 10^{9} / \mathrm{L}\right)$ & $344.25 \pm 38.10^{\mathrm{a}}$ & $457.00 \pm 0.00^{\mathrm{b}}$ & $201.67 \pm 93.68^{\mathrm{b}}$ & $445.00 \pm 0.00^{\mathrm{b}}$ \\
\hline Mean corpuscular vol. $(\%)$ & $57.10 \pm 1.26^{\mathrm{a}}$ & $61.10 \pm 0.00^{\mathrm{b}}$ & $58.80 \pm 1.34^{\mathrm{a}}$ & $58.10 \pm 0.00^{\mathrm{a}}$ \\
\hline $\begin{array}{l}\text { Mean corpuscular Haemoglobin } \\
(\rho g)\end{array}$ & $17.58 \pm 0.39^{\mathrm{a}}$ & $18.00 \pm 0.00^{\mathrm{a}}$ & $18.47 \pm 0.12^{\mathrm{a}}$ & $58.10 \pm 0.00^{\mathrm{b}}$ \\
\hline $\begin{array}{l}\text { Mean corpuscular haemogblobin } \\
\text { conc. }(\mathrm{g} / \mathrm{dL})\end{array}$ & $30.65 \pm 0.18^{\mathrm{a}}$ & $29.50 \pm 0.00^{\mathrm{a}}$ & $31.57 \pm 0.61^{\mathrm{a}}$ & $17.10 \pm 0.00^{\mathrm{b}}$ \\
\hline
\end{tabular}

Values are presented as mean \pm SEM $(n=5)$. Values with different superscripts across a row are significantly different from the control at $\mathrm{p}<0.05$. 
Table 2: Effect of diclofenac sodium on biochemical parameters of albino Wistar rats.

\begin{tabular}{lllll}
\hline Parameters & \multicolumn{4}{c}{ Doses of diclofenac sodium (mg/kg body weight) } \\
\cline { 2 - 5 } & $\begin{array}{l}\text { Group 1 } \\
\text { (control) }\end{array}$ & $\begin{array}{l}\text { Group 2 } \\
\mathbf{( 4 9 . 0 5 )}\end{array}$ & $\begin{array}{l}\text { Group 3 } \\
\mathbf{( 9 8 . 1 0 )}\end{array}$ & $\begin{array}{l}\text { Group 4 } \\
(\mathbf{1 4 7 . 1 5})\end{array}$ \\
\hline Glucose $(\mathrm{mg} / \mathrm{dL})$ & $57.65 \pm 18.38^{\mathrm{a}}$ & $7.40 \pm 0.00^{\mathrm{b}}$ & $41.70 \pm 14.86^{\mathrm{a}}$ & $66.10 \pm 0.00^{\mathrm{a}}$ \\
AST $(\mathrm{IU} / \mathrm{L})$ & $276.13 \pm 51.87^{\mathrm{a}}$ & $1181.7 \pm 0.00^{\mathrm{b}}$ & $192.35 \pm 229.18^{\mathrm{a}}$ & $621.0 \pm 0.00^{\mathrm{b}}$ \\
ALT $(\mathrm{IU} / \mathrm{L})$ & $93.75 \pm 9.62^{\mathrm{a}}$ & $182.60 \pm 0.00^{\mathrm{b}}$ & $38.10 \pm 4.56^{\mathrm{b}}$ & $104.8 \pm 0.00^{\mathrm{b}}$ \\
Alkaline phosphatase $(\mathrm{IU} / \mathrm{L})$ & $153.0 \pm 3.89^{\mathrm{a}}$ & $5521.0 \pm 0.00^{\mathrm{b}}$ & $214.0 \pm 2.79^{\mathrm{b}}$ & $136.0 \pm 0.00^{\mathrm{a}}$ \\
Total bilirubin $(\mu \mathrm{mol} / \mathrm{L})$ & $1.13 \pm 0.75^{\mathrm{a}}$ & $7.56 \pm 0.00^{\mathrm{b}}$ & $2.71 \pm 0.60^{\mathrm{b}}$ & $4.18 \pm 0.00^{\mathrm{b}}$ \\
Total protein $(\mathrm{g} / \mathrm{dL})$ & $6.85 \pm 0.18^{\mathrm{a}}$ & $7.07 \pm 0.00^{\mathrm{a}}$ & $4.55 \pm 0.33^{\mathrm{b}}$ & $3.38 \pm 0.00^{\mathrm{b}}$ \\
Albumin $(\mathrm{g} / \mathrm{dL})$ & $3.95 \pm 0.25^{\mathrm{a}}$ & $1.30 \pm 0.00^{\mathrm{b}}$ & $1.15 \pm 0.29^{\mathrm{b}}$ & $1.00 \pm 0.00^{\mathrm{b}}$ \\
Total cholesterol $(\mathrm{mg} / \mathrm{dL})$ & $59.50 \pm 4.21^{\mathrm{a}}$ & $86.0 \pm 0.00^{\mathrm{b}}$ & $62.0 \pm 7.42^{\mathrm{a}}$ & $50.0 \pm 0.00^{\mathrm{a}}$ \\
HDL cholesterol $(\mathrm{mmol} / \mathrm{L})$ & $1.21 \pm 0.06^{\mathrm{a}}$ & $0.32 \pm 0.00^{\mathrm{b}}$ & $0.38 \pm 0.17^{\mathrm{b}}$ & $0.81 \pm 0.00^{\mathrm{b}}$ \\
Triglycerides $(\mathrm{mg} / \mathrm{dL})$ & $66.0 \pm 15.16^{\mathrm{a}}$ & $147.0 \pm 0.00^{\mathrm{b}}$ & $109.0 \pm 4.16^{\mathrm{b}}$ & $152.0 \pm 0.00^{\mathrm{b}}$ \\
Urea $(\mathrm{mg} / \mathrm{dL})$ & $8.20 \pm 0.68^{\mathrm{a}}$ & $23.90 \pm 0.00^{\mathrm{b}}$ & $23.7 \pm 4.26^{\mathrm{b}}$ & $15.0 \pm 0.00^{\mathrm{b}}$ \\
Creatinine $(\mu \mathrm{mol} / \mathrm{L})$ & $48.34 \pm 3.35^{\mathrm{a}}$ & $81.07 \pm 0.00^{\mathrm{b}}$ & $57.33 \pm 11.67^{\mathrm{b}}$ & $56.78 \pm 0.00^{\mathrm{b}}$ \\
Sodium ions $(\mathrm{mmol} / \mathrm{L})$ & $155.89 \pm 3.30^{\mathrm{a}}$ & $143.45 \pm 75^{\mathrm{b}}$ & $131.0 \pm 6.20^{\mathrm{b}}$ & $232.2 \pm 0.00^{\mathrm{b}}$ \\
Potassium ions $(\mathrm{mmol} / \mathrm{L})$ & $5.93 \pm 0.39^{\mathrm{a}}$ & $6.46 \pm 0.46^{\mathrm{a}}$ & $6.99 \pm 0.52^{\mathrm{a}}$ & $12.99 \pm 0.00^{\mathrm{b}}$ \\
Chloride ions $(\mathrm{mmol} / \mathrm{L})$ & $100.17 \pm 2.77^{\mathrm{a}}$ & $101.42 \pm 1.39^{\mathrm{a}}$ & $97.67 \pm 3.44^{\mathrm{a}}$ & $162.27 \pm 0.00^{\mathrm{b}}$ \\
\hline
\end{tabular}

Values are mean \pm SEM $(n=5)$. The values with different superscripts across a row are significantly different from the control at $\mathrm{p}<0.05$.

\section{DISCUSSION}

The significant alterations in haematological parameters of rats treated with diclofenac sodium may provide evidence of toxicity. The significant reduction in $\mathrm{PCV}$, $\mathrm{RBC}$ and $\mathrm{Hb}$ values in groups 3 and 4 may suggest drug-induced toxicity, characterized by excessive destruction of red blood cells resulting in anaemia (Enendu et al., 2016). It may also be due to loss of erythrocytes as a result of gastrointestinal bleeding. When there is a substantial loss of blood from the body, the $\mathrm{RBC}$ picture may indicate microcytic hypochromic anaemia. This type of anaemia shows an increase in MCV and decrease in MCHC (Kahn and Scott, 2010, Okolo et al., 2015). The findings in the present study are in agreement with those of Basavraj et al. (2012), who showed that diclofenac sodium at $9.5 \mathrm{mg} / \mathrm{kg}$ orally administered for 28 days in albino Swiss mice induced significant decreases in $\mathrm{Hb}$ and PCV values. Similar findings were observed by El-Maddawy and El-Ashmawy (2013), who reported that administration of diclofenac sodium to adult male rats at a dose of $13.5 \mathrm{mg} / \mathrm{kg}$ by i/m route for 14 days induced significant reduction in $\mathrm{Hb}, \mathrm{PCV}, \mathrm{RBC}$ and $\mathrm{WBC}$ values compared to the control. Saches et al. (2004) also reported that diclofenac sodium is a widely used NSAID implicated as the cause of immune haemolytic anaemia.

The significant decrease in white blood cells counts observed in the treatment groups may be due to decrease in feed intake by the subjects, as was observed in the course of this experiment. This is in agreement with earlier studies which showed that decreased feed intake may have a major impact on the haematopoietic system and has been observed 
to decrease white blood cells, platelets and reticulocytes counts (Miyata et al., 2009). Although Al-Saady et al. (2011) observed that diclofenac causes no significant change in WBC count but it causes significant neutropenia and lymphocytosis within study period probably due to immune modulatory effects. The decreases in WBC, granulocytes and lymphocytes counts observed in our study may therefore be attributed to the decrease in feeds consumption, due to the debilitating effects of the drug.

The significant alterations observed in the biochemical indices of rats showed that intramuscular administration of diclofenac sodium at the given doses may cause hepatotoxicity and nephrotoxicity. The activities of AST, ALT and ALP are commonly used as biochemical indicators of liver functions. Structural and functional alterations in the liver result in elevated levels of these enzymes in circulation (Ahmad et al., 2012). The levels of these aminotransferases (ALT and AST) in serum are elevated in all liver diseases. In fact, very high levels of more than 1000 units can be seen in acute hepatitis (Vasudevan and Sreekumari, 2007). These enzymes are intracellular, thus their normal blood levels are very low, but when there is hepatocellular damage or necrosis of the liver cells (Wamutu et al., 2012), they leak out into the blood circulation, drastically increasing their levels in blood (Ahmad et al., 2012). Thus, the increased serum AST and ALT levels in our findings may provide preliminary evidence of liver impairments in the diclofenac-treated groups. These findings are similar to that of El-Maddawy \& ElAshmawy (2013), who reported that diclofenac sodium causes hepatotoxicity, inducing a rise in liver enzymes such as AST, ALT \& ALP, resulting in hepatitis. Our findings are also in agreement with Basavraj et al. (2012), who reported that administration of diclofenac sodium at the dose of $9.5 \mathrm{mg} / \mathrm{kg}$ per os for 28 days in albino Swiss mice induces significant increases in AST and ALT values.

The significant increase of serum alkaline phosphatase (ALP) levels observed is also attributed to liver impairment, as this indicates cholestatic alterations in the liver biliary ducts, which may be due to the effect of diclofenac sodium. The ALP levels are usually elevated as a result of cholestasis or biliary obstructions and this is used as a marker of hepatobiliary dysfunctions (Vasudevan and Sreekumari, 2007). Our findings are in agreement with Ahmad et al. (2012) and El-Maddawy and El-Ashmawy (2013), who observed significant increases in the levels of serum ALP after administration of diclofenac sodium. The significant increase in serum total bilirubin observed in all treated groups may be due to liver impairments, as a result of the given doses of diclofenac sodium. Serum bilirubin is one of the markers of liver impairments, as it tests for hepatic excretory function. Bilirubin is the excretory product formed by the catabolism of heme, which is normally conjugated by the liver to form bilirubin diglucuronide and excreted through the bile, so elevated serum bilirubin is seen when there is liver impairment (Dhanotiya, 2004). Serum bilirubin is also elevated when there is excessive breakdown of erythrocytes such as in haemolytic anaemia, which may be caused by diclofenac sodium. The heme formed from breakdown of haemoglobin derived from red blood cells is catabolized by the reticulo-endothelial system (RES) to produce bilirubin (Murray, 2006).

The significant decrease in serum levels of albumin and total protein observed in this study may also be indicative of liver impairment. Serum albumin is quantitatively the most important protein synthesized by the hepatocytes and reflects the extent of functioning liver cell mass. Therefore, decreased serum levels of albumin and 
consequently total proteins occur when there is impairment in the synthesizing function of the liver (Vasudevan and Sreekumari, 2007). Total protein and albumin levels may also decrease due to protein-losing nephropathy, haemorrhage, dietary protein deficiency and nutrients malabsorption (Kahn and Scott, 2010). Thus, the decreases in serum total protein and albumin may also be due to haemorrhage in the gastrointestinal tract as a result of toxic effect of the drug, nutrient malabsorbtion and reduced feed intake. These findings are in agreement with El-Maddawy and El-Ashmawy (2013), who observed significant decreases in serum total protein and albumin levels in rats treated with diclofenac sodium at a dose of $13.5 \mathrm{mg} / \mathrm{kg}$ for 14 days and compatible with an earlier scientific report (Basavraj et al., 2012).

The significant alterations observed in serum total cholesterol, triglycerides and HDL-cholesterol in all the treated groups may be due to the effect of diclofenac sodium. Cholesterol may increase due to hepato-biliary disease and protein-losing nephropathy. The increase in the serum levels of total cholesterol and triglycerides, and the decrease in the serum levels of HDL-cholesterol may be attributed to the toxic effect of the drug, leading to hepatobiliary disorders and impaired cholesterol metabolism. These findings are in agreement with Maity et al. (2012) who reported sharp increase in serum cholesterol and triglyceride levels in diclofenac-treated rats. The lipids which accumulate in the liver cells are mainly triglycerides but are transported to peripheral tissues by lipoproteins. However, hepatotoxins that cause deficiency of lipoproteins prevent triglycerides transport, so they remain in the hepatocytes and cause lysis of the cells, resulting in an increase in serum triglycerides level (Singh et al., 2006). The liver has a major role in controlling the plasma levels of LDL-cholesterol. It synthesizes cholesterol, removes cholesterol from lipoprotein remnants, converts cholesterol to bile acids and is the only organ that can excrete cholesterol through bile. Thus, when there is drug-induced liver impairment, there will be elevated levels of serum cholesterol and the level of HDLcholesterol will be decreased (Vasudevan and Sreekumari, 2007). It is also well known that elevated levels of total cholesterol, triglycerides, LDL-cholesterol and reduced level of HDL-cholesterol are risk factors for cardiovascular diseases, atherosclerosis, hypertension and stroke. The significant decrease in glucose levels in the treated groups may also be attributed to the toxic effect of diclofenac sodium affecting liver functions, because the liver plays a major role in maintaining glucose level in blood. This observation is similar to that of Makki et al. (2014) who observed significant reduction in random plasma glucose after one month of treatment with diclofenac sodium. The liver is the only organ that can replenish blood glucose through gluconeogenesis. So when there is reduced diet intake, coupled with liver impairments, the blood glucose level would decrease (Vasudevan and Sreekumari, 2007).

The significant increase in serum levels of urea and creatinine observed in all treatment groups may be due to nephrotoxic effect of the drug, leading to reduced renal function. Creatinine and urea levels are used as markers of kidney function, but the test for creatinine is more sensitive than urea (Vasudevan and Sreekumari, 2007). Thus, elevated serum levels of urea and creatinine may indicate kidney injury, with resultant reduced glomerular filtration. The results of this study agree with the findings of Syed et al. (2012) who reported renal function impairment by diclofenac sodium, as this drug increased serum urea and creatinine levels in rabbits. Urea is formed in the liver, 
representing the principal waste product of protein catabolism and is excreted by the kidney. Diclofenac sodium probably causes a decrease in glomerular filtration rate, resulting in decreased excretion of urea, which may produce an increase in the concentration of the blood urea (Ahmad et al., 2012). It was earlier reported that diclofenac inhibits cyclooxygenases, thereby suppressing the production of prostaglandins, which play an important role in maintaining glomerular filtration rate of the kidneys (Hörl, 2010; Dhanvijay et al., 2013). Creatinine is a nonprotein nitrogenous substance formed from creatine and phosphocreatine during muscle metabolism. It is also removed from blood by glomerular ultrafiltration of the kidneys. As with urea, its rate of removal is influenced by glomerular filtration rate (GFR), and any abnormalities that decrease GFR will result in an increased serum creatinine (Juhlin et al., 2004). Previous studies have shown that an apparently minor increase in serum creatinine can reflect a marked decrease in glomerular filtration rate (Salomon et al., 2003). Thus, diclofenac sodium at the given doses may alter renal functions through its effect on renal prostaglandins, leading to reduced GFR and accumulation of both creatinine and urea in blood.

Serum electrolytes $\left(\mathrm{Na}^{+}, \mathrm{K}^{+}, \mathrm{Cl}^{-}\right)$ estimations are among the tests of kidney function. The significant elevations in serum electrolytes; potassium, sodium, and chloride ions levels seen in this study may be due to the toxic effect of diclofenac sodium on the kidneys, resulting in reduced GFR and excretion of the ions. This is in agreement with Dhanvijay et al. (2013) who earlier observed increases in electrolytes, induced by administration of diclofenac sodium. The kidneys secrete potassium $\left(\mathrm{K}^{+}\right)$ ions, reabsorbs $85 \%$ of sodium $\left(\mathrm{Na}^{+}\right)$and chloride $\left(\mathrm{Cl}^{-}\right)$ions and also functions in the excretion of these electrolytes (ions), in order to maintain acid-base balance under normal physiological conditions (Vasudevan and Sreekumari, 2007). Failure in the regulatory functions of the kidney leads to abnormally high or low levels of these ions in the blood, due to reduced GFR and rate of secretion of these ions. The inhibition of renal prostaglandins synthesis by NSAIDs causes various electrolytes and acid-base disturbances including sodium retention, hyponatremia, hyperkalemia and decreased renal function (Kim and Joo, 2007). Hypernatremia may also be seen in edema and dehydration while Hyperkalemia is seen in decreased urinary output, increased haemolysis and tissue necrosis. Since the normal level of potassium ions is kept at a very narrow margin, even a small increase is life-threatening. Hyperchloremia occurs in dehydration, severe diarrhoea and renal tubular acidosis (Vasudevan and Sreekumari, 2007). Thus the observed elevations in serum electrolytes levels may be as a result of reduced renal excretion, leakage of cellular ions, or severe tissue injury, due to the doses of diclofenac sodium administered. These findings are in agreement with Juhlin et al. (2004) who demonstrated that acute administration of diclofenac induces significant decrease in GFR, urine flow, excretion rates of sodium and potassium in patients with congestive heart failure.

Our findings have shown that the given doses of diclofenac sodium may cause significant alterations in the haematological and biochemical indices of rats. It can therefore be concluded that diclofenac sodium at the various doses and duration of study might cause adverse effects on vital animal tissues, resulting in haematological disorder, hepatic and renal impairments. So the safe dose of this drug might be lower than the doses used in this study. Thus, caution should be exercised in the clinical 
use of this drug for therapeutic purpose, which should be limited to the lowest dose and treatment duration required to achieve the best therapeutic effect. It is recommended that further toxicological studies be performed on diclofenac sodium using other animal species, with the aim of determining safe therapeutic doses of the drug in different animal species.

\section{COMPETING INTERESTS}

The authors declare that they have no competing interests.

\section{AUTHORS' CONTRIBUTIONS}

AYA was the project leader; RJO was responsible for experimental design and interpretation of results, while $\mathrm{OAO}$ processed the samples and performed the experiments.

\section{ACKNOWLEDGEMENTS}

The technical assistance of Laboratory Technologists, Mr. Simon Ogbole and Mrs. Mary Orkwa, at the Clinical Chemistry and Haematology laboratories of Federal Medical Center, Makurdi, Nigeria, was highly appreciated.

\section{REFERENCES}

Ahmad I, Qureshi TA, Khan FA, Mughal SAK, Sadique U, Shah Z, Khan S, Hassan ZU. 2012. Evaluation of Biochemical effects of dioclofenac sodium in goats. J. Anim. Plant Sci., 22(2): 1-4.

Akhila JS, Deepa S, Alwar MC. 2007. Acute toxicity studies and determination of median lethal dose. Curr. Sci., 93(7): 917-920.

Al-Saady MAJ, Abdul-Latif A, Al-Shemmery HN. 2011. Pharmacological effects of diclofenac sodium on some haematological parameters of male Rabbits. Med. J. Babyl., 8(3): 441-452.
Aydin G, Gokcimen A, Oncu M, Clcek E, Karahan N, Golkalp O. 2003. Histopathologic changes in liver and renal tissues induced by different doses of diclofenac sodium in rats. Turk. $J$. Vet. Anim. Sci., 27: 1131-1140.

Baker FJ, Silverton RE, Pallister CJ. 2001. Baker and Silverton's Introduction to Medical Laboratory Technology $\quad\left(7^{\text {th }}\right.$ edn). Bounty Press: London.

Basavraj ST, Fefar DT, Prajapati KS, Jivani BM, Thakor KB, Patel JH, Ghodasara DJ, Joshi BP, Undhad VV. 2012. Haematobiochemical alterations induced by diclofenac sodium toxicity in Swiss albino mice. Vet. World, 5(7): 417-419. DOI: $10.14202 /$ vetworld.2016.875-881

Boothe DM. 2001. The Analgesic, Antipyretic, Anti-inflammatory Drugs. In Veterinary Pharmacology and Therapeutics (8th edn), Adams HR (ed). The Iowa State University Press: Iowa; 432-449.

Cheesbrough M. (2002). District Laboratory Practice in Tropical Countries, Part 2. Cambridge University Press: New York.

Crofford LJ. 2013. Use of NSAIDs in treating patients with arthritis. Arth. Res. Ther., 15(3): S2.

Da Silva HS, De farias furlado ST, De Souza DA, De Oliveira LCM, De Oliveira CA, Benedetta G. 2013. Study of blood and pubic hair mineralograms of alchoholic people. Int. J. Biol. Chem. Sci., 7(2): 809-818.

DOI: http://dx.doi.org/10.4314/ijbcs.v7i2.36

Dhanotiya RS. 2004. Textbook of Veterinary Biochemistry $\left(7^{\text {th }}\right.$ edn). Jaypee Brothers Medical Publishers Ltd: New Delhi.

Dhanvijay P, Misra AK, Varma SK. 2013. Diclofenac-induced acute renal failure in a decompensated elderly patient. $J$. Pharmacol. Pharmacother., 4(2):155157. DOI: 10.4103/0976-500X.110916. 
El-Maddawy ZKH, El-Ashmawy IM. 2013. Hepato-Renal and Haematological effects of diclofenac sodium in Rats. Global J. Pharmacol., 7(2): 123-132. DOI: 10.5829/idosi.gjp.2013.7.2.72171

Enendu AC, Unekwe PC, Esimone CO, Obi E, Chilaka KC. 2016. Protective effect of phenylalanine and glycine on chloramphenicol-induced bone marrow toxicity in albino rats infected with Klebsiella Pneumoniae. Int. J. Biol. Chem. Sci., 10(1): 369-383. DOI: http://dx.doi.org/10.4314/ijbcs.v10i1.28

Harris RC. 2006. COX-2 and the kidney. J. Cardiovas. Pharmacol., 47: S37-S42.

Hörl WH. 2010. Non-steroidal Antiinflammatory Drugs and the kidney. Pharmaceuticals, 3: 2291-2321.

Juhlin T, Bjorkman S, Gunnarsson B, Fyge A, Roth B, Hoglund P. 2004. Acute administration of diclofenac but possibly not long term low dose aspirin, causes detrimental renal effects in heart failure patients treated with ACE-inhibitors. Eur. J. Heart Fail., 6(7): 909-916. DOI: 10.1016/J.ejheart.2004.02.005

Kahn CM, Scott L. 2010. General and Introductory Veterinary Medicine. Merck Veterinary Manual $\left(10^{\text {th }}\right.$ edn). Merck \& Co. Inc.: London.

Kim S, Joo KW. 2007. Electrolyte and Acidbase disturbances associated with Nonsteroidal Anti-inflammatory Drugs. Electrol. Blood pres., 5:116-125.

Lo V, Meadows SE, Saseen J. 2006. When should COX-2 selective NSAIDs be used for osteoarthritis and rheumatoid arthritis? J. Fam. Pract., 55: 260-262.

Maity T, Ahmad A, Pahari N, Ganguli S. 2012. Hepatoprotective activity of Mikania scandens (L.) Willd. against diclofenac sodium-induced liver toxicity in rats. Asian J. Pharmaceut. Clin. Res., 5(2): 185-189.
Makki MJA, Jawad AM, Umran HJ. 2014. The effect of diclofenac sodium given alone or in combination with paracetamol in treatment of patients with type-2 diabetes mellitus. The Med. J. Basra Univ., 32(1): 22-29.

Miyata H, Asanuma F, Iwaki Y, Kimura M, Matsumoto K. 2009. Evaluation of myelotoxicity in dietary restricted rats. $J$. Toxicol. Pathol., 22(1): 53-63.

Murray RK. 2006. Porphyrins and bile pigments. Harper's illustrated Biochemistry $\left(27^{\text {th }}\right.$ edn). Mc Graw-Hill Inc.: Singapore.

Neal MJ. 2012. Drug metabolism. Medical Pharmacology at a Glance $\left(7^{\text {th }}\right.$ edn). John Wiley and Sons Inc.: London.

Okolo I, Owolabi OA, James BD, Sallau AB, Andongma BT, Moses CA. 2015. The haemoglobin regeneration potential of fermented and unfermented Telfaira occidentalis and Gnetum africanus leaves in iron deficient albino rats. Int. J. Biol. Chem. Sci., 9(4): 1742-1754. DOI: http://dx.doi.org/10.4314/ijbcs.v9i4.1

Ong CKS, Lirk P, Tan CH, Seymour RA. 2007. An evidence-based update on nonsteroidal anti-inflammatory drugs. Clin. Med. Res., 5(1): 19-34. DOI: 10.3121/cmr.2007.698.

Saches S, Santoso L, Roder E, Mark S, Bein G, Kroll H. 2004. Diclofenac-induced antibodies against red blood cells are heterogeneous and recognize different epitopes. Transfus. J., 44(8):1226-1230. DOI: $10.1117 /$ j.1537-2995.2004.04025x

Saganuwan AS. 2012. Principles of pharmacological calculations $\left(1^{\text {st }}\right.$ edn $)$. A. B. U. Press: Zaria, Nigeria.

Salomon L, Levu S, Deray G, Launay-Vacher V, Brucker G, Ravaud P. 2003. Assessing residents' prescribing behavior in renal impairment. Internat. J. Qual. Health Care, 15(3):235-240. 
Singh B, Chandan BK, Sharma N, Bhardwaj V, Satti NK, Gupta VN, Gupta BD, Suri KA, Suri OP. 2006. Isolation, structure elucidation and in vivo hepatoprotective potential of trans-Tetracos-15-enoic acid from Indigofera tinctoria Linn. Phytother. Res., 20(10): 831-839. DOI:10.1002/ptr.1856.

Suckow MA, Stevens KA, Wilson RP. 2012. Ethical considerations and regulatory issues. In The Laboratory Rabbit, Guinea Pig, Hamster, and other Rodents. Academic Press Inc.: San Diego.

Syed NI, Zehra F, Syed AA, Karim S, Khan FS. 2012. Comparing the effects of salts of diclofenac and alminoprofen with aspirin on serum electrolytes, creatinine and urea levels in rabbits. Pak. J. Pharmaceut. Sci., 25(4): 777-782.
Vasudevan DM, Sreekumari S. 2007. Textbook of biochemistry for medical students $\left(5^{\text {th }}\right.$ edn). Jaypee Brothers Medical Publishers Ltd: New Delhi.

Wamutu S, Francque S, Chatterjee S, Musisi E, Muyombya GW, Van Marck E, Bimenya GS, Michielsen P. 2012. Vitamin $\mathrm{C}$ as well as beta-Carotene attenuates experimental liver fibrosis after intoxication with carbon tetrachloride in rats. Int. J. Biol. Chem. Sci., 6(2): 559-571. DOI: http://dx.doi.org/10.4314/ijbcs.v6i2.1

Weir MR. 2002. Renal effects of nonselective Non Steroidal Antiinflammatory Drugs and Coxibs. Cleveland Clin. J. Med., 69(1): SI-53 SI-58. 